\section{Michał Zembrzuski}

Uniwersytet Kardynała Stefana Wyszyńskiego w Warszawie m.zembrzuski@uksw.edu.pl

DOI: http://dx.doi.org/10.12775/BPTh.2016.026

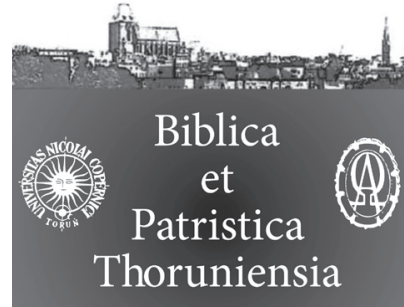

9 (2016) 3: 149-159

ISSN (print) 1689-5150

ISSN (online) 2450-7059

\title{
$A b$ intus legere Scripturam. The Role of Understanding (intellectus) in the Biblical Exegesis of Thomas Aquinas
}

\section{$A b$ intus legere Scripturam. Znaczenie rozumienia (intellectus) w egzegezie biblijnej Tomasza z Akwinu}

\begin{abstract}
The aim of the article is to show the intellectual character of biblical exegesis of Thomas Aquinas. The problem is presented from the perspective of the gift of understanding (donum intellectus), contemplation and issues of the word of the heart (verbum cordis). Thomas's exegesis is not intellectualistic (erudite) or existential and it is not only based on the division of the biblical text. His exegesis originates from a deep reading of reality (a serious practice of metaphysics), the knowledge of the tradition, especially the Fathers of the Church, as well as religious life, whose cause is God (natural and supernatural efficiency).
\end{abstract}

Streszczenie. Celem artykułu jest ukazanie intelektualnego charakteru egzegezy biblijnej Tomasza z Akwinu. Problem przedstawiony jest z perspektywy daru rozumienia (donum intellectus), kontemplacji, a także zagadnienia słowa serca (verbum cordis). Egzegeza Tomasza nie jest intelektualistyczna (erudycyjna), nie jest także egzystencjalna, nie polega także wyłącznie na dzieleniu tekstu biblijnego. Egzegeza wyrasta z głębokiego wczytania się w rzeczywistość (poważnego uprawiania metafizyki), poznania tradycji (szczególnie Ojców Kościoła), a także życia religijnego, którego przyczyną jest Bóg (sprawności naturalne i nadnaturalne).

Keywords: Thomas Aquinas; intellect; gift of the intellect; contemplation; Biblical Thomism.

Słowa kluczowe: Tomasz z Akwinu; intelekt; dar intelektu; kontemplacja; tomizm biblijny. 


\section{Introduction}

ne problem that every reader encounters is the understanding of what was meant to be conveyed. This is similar to what we see, hear, and generally recognize. In his Commentary on Sentences Aquinas observes that "you should not read if you read without understanding. Reading without understanding is

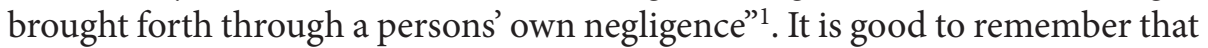
negligence is a form of ignorance, and one that a person accepts. Therefore only he can be burdened with the consequences ${ }^{2}$. Of course, a person does not have to understand everything from what he has read, but only what is truly significant (quod est debitum). If Aquinas read and commented on authors' words, especially the ones of Aristotle and the Bible, then, without any doubt, he did so with the utmost understanding.

To highlight the role of understanding in Thomas's exegesis I will divide my reflection into three parts. First, I will explain Thomas's conviction of why someone should read with understanding, where understanding is viewed as one of the gifts of the Holy Spirit, and intellect, which plays a special part in its obtainment. Next, I will stress contemplation as a proper operation of the intellect, as it is written in Commentary on the Gospel of John. Lastly, I will focus on the role of spoken word and "the word of the heart" also in the context which is explained in Commentary on John. The aim of it is to show that Aquinas did not read the Bible from "the outside" but more from "the inside" ( $a b$ intus), and therefore his exegesis can, without any doubt, be described as intellectual (and not only as existential or intellectualistic).

1 “[...] nullus congrue legit qui non intelligit quod legit: quia legere et non intelligere, negligere est”. Super Sent., lib. 4, d. 24, q. 1, a. 3, qc. 2, arg. 3.

2 "Dicendum quod cum de ratione peccati sit quod sit voluntarium, in tantum ignorantia habet excusare peccatum in toto vel in parte, in quantum tollit voluntarium. Est autem considerandum, quod ignorantia voluntarium sequens tollere potest, non autem voluntarium praecedens. Cum autem ignorantia sit in intellectu, ordo ignorantiae ad voluntarium considerari potest ex ordine intellectus ad voluntatem; praecedit enim ex necessitate actus intellectus actum voluntatis, quia bonum intellectum est voluntatis obiectum; et ideo sublata cognitione intellectus per ignorantiam, aufertur voluntatis actus; et sic tollitur voluntarium quantum ad id quod est ignoratum. [...] Et quamvis semper ignorantia causet non voluntarium, non tamen semper causat involuntarium”. De malo, q. 3, a. 8 co. 


\section{Intellectus as a gift of the Holy Spirit}

In the Summa Theologiae Aquinas defines donum itellectus, as the gift of understanding, and if someone wants to define it as the gift of reason it is considered to be inappropriate ${ }^{3}$. Reasoning is the passing from what we know into that which we do not. Even if understanding what was read begins and seems to end with the same knowledge it is not so. Understanding concerns itself with perfecting that which is already known. A human reasons and gets from understanding $\mathrm{X}$ to understanding $\mathrm{Y}$, which was not known before, whereas in the case of understanding just $\mathrm{X}$ or just $\mathrm{Y}$ through penetration and understanding he can achieve better understanding of himself. Due to this matter reasoning is the reading of what is inside (intus legere), it is a penetration in the interior (intima penetrare $)^{4}$. In Commentary on the Sentences Thomas uses the expression "through intellect entering inside" comparing intellect to "walking through the doors"; "you can only venture inside through that which you find around you, like some door" 5 .

Thus defining in this way intellect and self-understanding Thomas leaves no question for his comments and immediately gives the example of "intellectual penetration": a) intellect by accidents penetrates the nature of the substantial reality; b) intellect by the words penetrates their meaning; $c$ ) intellect by the likenesses and figures penetrates the truth; $d$ ) intellect by the sensible world penetrates the intelligible world, which is enclosed within; e) intellect by effects penetrates their causes and vice versa ${ }^{6}$.

$3 \ldots[\ldots]$ discursus rationis semper incipit ab intellectu et terminatur ad intellectum, ratiocinamur enim procedendo ex quibusdam intellectis, et tunc rationis discursus perficitur quando ad hoc pervenimus ut intelligamus illud quod prius erat ignotum. Quod ergo ratiocinamur ex aliquo praecedenti intellectu procedit. Donum autem gratiae non procedit ex lumine naturae, sed superadditur ei, quasi perficiens ipsum. Et ideo ista superadditio non dicitur ratio, sed magis intellectus, quia ita se habet lumen superadditum ad ea quae nobis supernaturaliter innotescunt sicut se habet lumen naturale ad ea quae primordialiter cognoscimus". S. Th. II-II, q. 8, a. 1, ad 2. In the Polish language it is often used to define the gift of reason. See: K. Romaniuk, O siedmiu Darach Ducha Świętego, pp. 44-49; 55-60.

4 „Sed cum cognitio hominis a sensu incipiat, quasi ab exteriori, manifestum est quod quanto lumen intellectus est fortius, tanto potest magis ad intima penetrare". S.Th. II-II, q. 8 , a. 1 , co.

5 „Aliquando vero ad intima non pervenitur nisi per circumposita quasi per quaedam ostia [...]". Super Sent. lib. 3, d. 35, q. 2, a. 2, qc. 1, co.

6 „Sunt autem multa genera eorum quae interius latent, ad quae oportet cognitionem hominis quasi intrinsecus penetrare. Nam sub accidentibus latet natura rerum substantialis, sub verbis latent significata verborum, sub similitudinibus et figuris latet veritas figurata: res 
The gift of intellect, according to the definition given earlier, is an ability (some kind of light - alongside the natural light which is agent intellect) to understand the truth given to believe and overall understanding of its depths ${ }^{7}$. This formulation which primarily explains what intellect is, and only then is referred to as the gift of intellect, is extended to the determination of intellectual cognition in comparison with sensitive cognition. "Sensitive knowledge is concerned with external sensible qualities, whereas intellective knowledge penetrates into the very essence of a thing". It is worth highlighting that also in the context of what is spoken to us, the gift of intellect is used as if to emphasize 'what is said' characteristics of intellectual knowledge "the object of the intellect is what a thing is (quidditas)", which is crucial to understand the exegesis of the Holy Scripture. To complement this reflection on intellect, it is necessary to add the topic of the dual method for cognition. The first one is related to the full penetration of the essence of things understood, reaching to the heart of the truth of expression understood. The second method, due to imperfect expression for the fact that even if the human intellect is not able to penetrate into what something is or what is the very essence of things, or the truth of the opinion, however, intellect grasp from the outside, and that what it seen in no way contradict the essence of the thing ${ }^{8}$. This formulation, though expressed in the natural order, can be referred to the issue of religious faith, which in this context gains credibility. A person, who has received the gift of intellect, receives the knowledge of the truth of his beliefs. In this context, these statements certainly can be applied to a typical argument ex convenientia, according

etiam intelligibiles sunt quodammodo interiores respectu rerum sensibilium quae exterius sentiuntur, et in causis latent effectus et e converso. Unde respectu horum omnium potest dici intellectus". S. Th. II-II, q. 8, a. 1, co.

7 „Lumen autem naturale nostri intellectus est finitae virtutis, unde usque ad determinatum aliquid pertingere potest. Indiget igitur homo supernaturali lumine ut ulterius penetret ad cognoscendum quaedam quae per lumen naturale cognoscere non valet. Et illud lumen supernaturale homini datum vocatur donum intellectus". S.Th. II-II, q. 8, a. 1, co; ad 2.

8 „Ex parte vero intellectus, distinguendum est quod dupliciter dici possumus aliqua intelligere. Uno modo, perfecte, quando scilicet pertingimus ad cognoscendum essentiam rei intellectae, et ipsam veritatem enuntiabilis intellecti, secundum quod in se est. Et hoc modo ea quae directe cadunt sub fide intelligere non possumus, durante statu fidei. Sed quaedam alia ad fidem ordinata etiam hoc modo intelligi possunt. Alio modo contingit aliquid intelligi imperfecte, quando scilicet ipsa essentia rei, vel veritas propositionis, non cognoscitur quid sit aut quomodo sit, sed tamen cognoscitur quod ea quae exterius apparent veritati non contrariantur; inquantum scilicet homo intelligit quod propter ea quae exterius apparent non est recedendum ab his quae sunt fidei". S. Th. II-II, q. 8, a. 2, co. 
to which the human intellect always works ${ }^{9}$. You can even refer to them in the exegesis of Thomas, where the apologetic defense against mistakes and charges, as well as wrong reaction towards the interpretation of the Bible often appear.

The light of human intellect is limited, and what may only come from that is limited as well ${ }^{10}$. Thomas explains how a man needs a supernatural light to further penetrate and get closer to what he cannot learn himself. Therefore, intellect is a supernatural gift of light, given to man to let him know what is inside of discovering reality and what can be learned in a natural way, but still imperfectly, as well as to understand what constitutes the content for supernatural faith ${ }^{11}$.

It is worth remembering that it was in Commentary on Isaiah that Aquinas indicates a unique gift of cognitive nature indicated by actions of the intellect, "this is very peculiar, the way that makes you clearly and distinctly watch what belongs to faith". It is very remarkable that the gift of intellect enables the vision of what has been heard ${ }^{12}$.

Talking about the truths given to believe, we cannot ignore the issues of truth itself. Aquinas demonstrates the relationship of the gift of intellect to the theological virtues of faith, just as it determines the perception of truth ${ }^{13}$. Faith is an acknowledgment as the truth of what is given to believe (assensus veritatis). Faith is strengthened by the Holy Spirit, who generally allows us to notice

9 See: P. Roszak, Wiarygodność i tożsamość. «Teologia wiary» św. Tomasza z Akwinu i współczesność, pp. 68-76.

10 J.-P. Torrell speaks in a similar manner. He says that in Aquinas's works the issue of the gifts of the Holy Spirit is always presented by some reasoning: if reason is enough for the achievement of a purely human order, it remains dramatically insufficient in relation to the supernatural, and that is why God gives us the grace and virtue. See: J.-P. Torrell, Święty Tomasz z Akwinu. Mistrz duchowy, p. 295.

11 S.Th. II-II, q. 8, a. 1, co.

12 "Circa primum sciendum est, quod, sicut dicit Gregorius, dona dantur in adjutorium virtutum, quibus perficiuntur potentiae animae ad actus proportionatos, secundum modum humanarum; sicut fides, quae facit videre in speculo et aenigmate. Est autem duplex imperfectio virtutis. Una per accidens, quae est ex indispositione habentis, ex qua indispositione manet in subjecto: et iste defectus tollitur per augmentum virtutis. Alius defectus est per se ex parte ipsius habitus; sicut fides secundum dispositionem est continue imperfecta, quia aenigmatica. Et iste defectus tollitur per altiorem habitum, qui vocatur donum, quia quasi excedit modum humanae operationis, a Deo datum; sicut donum intellectus, quod facit aliquo modo limpide et clare intueri quae sunt fidei". Super Is., cap. 11.

13 Cfr. A. Pinsent, The Gifts and Fruits of the Holy Spirit, pp. 477-479; Cfr. D. Milewski, A. Rycerz, Dar rozumu, pp. 85-95. 
truth in faith (veritatis perceptio) ${ }^{14}$. This plane shows human activity as a direct result of the intellect, and therefore penetrating that which was given. There is no way that a human can be directed to the good of his will, as long as there will be no previous knowledge and understanding of truth. The good that pulls a person is always good, in which intellect recognizing them as the true good ${ }^{15}$. Exegesis in Aquinas's works, referring to the gift of intellect, turns out to be the penetration of the truth of expression, made possible by the action of the Holy Spirit.

\section{Contemplative Intellect}

Aquinas's consideration of contemplation is led consistently under the consideration of the intellect. In order not to get confused, the earlier comments about the depth of penetration of an object of knowledge are in an angelic tone, because in some way they are opposed to reason, it is important to add some notes about a typical human contemplation. Contemplation of the truth, which is contained "between the lines" of Scripture, as a simple and special act, carried out first figuring out of cogitation (cogitatio) and meditation (meditatio) ${ }^{16}$.

14 "Ad tertium dicendum quod fides importat solum assensum ad ea quae proponuntur. Sed intellectus importat quandam perceptionem veritatis, quae non potest esse circa finem nisi in eo qui habet gratiam gratum facientem, ut dictum est. Et ideo non est similis ratio de intellectu et fide.. S. Th. II-II, q. 8, a. 5, ad 3. In Commentary on the Sentences Aquinas discusses the gift of intellect, observing that through it "we grasp spiritual beings as pure truth, which is made on the way over nature of man; and this makes the gift of intellect enlighten the mind by faith about what we heard, as Gregory says". Super Sent. lib. 3, d. 34 q. 1, a. 2, co. This sentence appears in the context of faith, which has been enlightened and enriched by the understanding about what faith has only by the word of mouth (by hearing). In the previous passage from Commentary on the Sentences, Aquinas also highlights the effect of the gift of intellect which allows somehow to 'see' what is seen: "Therefore faith which spiritual beings makes knowable in the curtain of mirror and puzzles, perfect the mind on the way to the right of man and, therefore, is a virtue. However, if the mind is so much elevated by supernatural light, it can be introduced to seeing these spiritual beings, and it occurs in human way. Does it makes this gift of intellect by enlightening the intellect on what is heard in such a way as is the case in the first principles recognized as soon as they hear". Super Sent. lib. 3, d. 35, q. 2, a. 2, qc. 1, co.

15 See: S.Th. II-II, q. 8, a. 4, co. According to Prof. M. Gogacz this function of the gift of intellect is directly called: "sentience into the truth". M. Gogacz, Modlitwa i mistyka, p. 70 .

16 Cfr. J. Idźkowski, Próba wyjaśnienia, czym jest kontemplacja według św. Tomasza $z$ Akwinu, pp. 65-70. Cfr. I. Andrzejuk, Człowiek i kontemplacja. Antropologiczne podstawy poznania Boga w rozumieniu Aleksandra Żychlińskiego, pp. 171-174. 
Life with contemplation, to which Aquinas encourages us, perfectly expresses the way for reading and understanding Scripture, "from the inside", and precisely consists in the contemplation of truth. In Commentary on Isaiah, Aquinas distinguishes three ways of seeing the intellectual and combines them with three types of contemplation: "There is a certain vision to which the light of the natural intellect suffices, and thus is the contemplation of the invisible by the principle of reason; and in this contemplation the philosophers placed the highest happiness of man. There is, moreover, a certain contemplation to which man is elevated more sufficiently by the light of faith, and this is in the manner of the saints. There is also a certain contemplation of the blessed in heaven [the Fatherland] to which the intellect is elevated by the light of glory, seeing God by his essence, as far as He is the object of beatitude; this is not complete or perfect unless it is in heaven [the Fatherland]"17.

These comments can be confronted with an incentive to a contemplative life (the Summa Theologiae) and suggest that being a teacher of sacra doctrina is an authentic dimension for both "exercising spiritual" as well as a unique way of life ${ }^{18}$. The first sentence from Commentary on the Gospel of John is key here (also, taken from the Book of Isaiah), Aquinas shows that the word "contemplation" can cover the whole Gospel of John ${ }^{19}$. Attributing the contemplation to three properties (height, width, and perfection) Thomas refers them to different areas of philosophy: moral knowledge, natural knowledge, and metaphysics. Perfection of contemplation is associated with moral knowledge indicating the ultimate goal. The fullness and the width of the contemplation are expressed in natural knowledge, which grasp physical reality and recognize the one as coming from God. And methaphysics indicates the height of contemplation by its

17 “[...] est enim quaedam visio ad quam sufficit lumen naturale intellectus, sicut est contemplatio invisibilium per principia rationis: et in hac contemplatione ponebant philosophi summam felicitatem hominis. Est iterum quaedam contemplatio ad quam elevatur homo per lumen fidei sufficienter, sicut sanctorum in via. Est etiam quaedam beatorum in patria ad quam elevatur intellectus per lumen gloriae, videns Deum per essentiam, inquantum est objectum beatitudinis; et hoc plene et perfecte non est nisi in patria”. Super Is., cap. 1, 1. 1.

18 Cfr. S.Th. I, q. 1, a. 4, co. See. T. Bellamah, The Interpretation of A Contemplative: Thomas' Commentary «Super Iohannem», pp. 229-255.

19 “"Vidi dominum sedentem super solium excelsum et elevatum, et plena erat omnis terra maiestate eius, et ea quae sub ipso erant, replebant templum». Is. VI, 1. Verba proposita sunt contemplantis, et si capiantur quasi ex ore Ioannis Evangelistae prolata, satis pertinent ad declarationem huius Evangelii”. Super Io., pr. 1. 
subject which is the first cause of reality and being along with its properties ${ }^{20}$. In this context, Aquinas observes that The Gospel of John is the most perfect, because it is an expression of full perfection, which is partially entitled to particular types of knowledge. If I could bring your attention to contemplating the characteristics of the Gospel of John (and also Commentary on the Book of Job) it extends to the entire understanding of Scripture, and justifies the Thomistic understanding of theology as a field of more (though not exclusively) contemplative than practical. It is certainly the actions of the intellect, consisting in the meaning of truth in the Scriptures, reaching out to God's Word through the written word and in this way it would be correct to define the most contemporary version of Thomism as Biblical Thomism ${ }^{21}$.

\section{The Word of Heart}

When Aquinas wrote about the excellence of contemplation in Commentary on the Gospel of John, he pointed out that it must be realized in "adherence and approval of the truth learned intellectually"22.

To show the proper role of the intellect in Aquinas's comments it must be emphasized that the human understanding of realization is always associated with the begetting of "the words of the heart" (verbum cordis), which operate within the framework of intellectual power - intellect and will. Thanks to the subject of the words of the heart we can touch on Thomas's intellect philosophy (epistemology). When Aquinas speaks of understanding (intelligere) as an act, he emphasizes the necessity of its range and fruit, which results in our un-

20 "Sed notandum quod diversimode diversae scientiae istos tres modos contemplationis sortiuntur. Perfectionem namque contemplationis habet scientia moralis, quae est de ultimo fine; plenitudinem autem scientia naturalis, quae res a Deo procedentes considerat; altitudinem vero contemplationis inter scientias physicas habet metaphysica. Sed Evangelium Ioannis, quod divisim scientiae praedictae habent, totum simul continet, et ideo est perfectissimum”. Super Io., pr. 1. Cfr. "Haec autem triplex consideratio, non diversis, sed uni scientiae attribui debet. Nam praedictae substantiae separatae sunt universales et primae causae essendi. Eiusdem autem scientiae est considerare causas proprias alicuius generis et genus ipsum: sicut naturalis considerat principia corporis naturalis. Unde oportet quod ad eamdem scientiam pertineat considerare substantias separatas, et ens commune, quod est genus, cuius sunt praedictae substantiae communes et universales causae”. Sententia Metaphysicae, pr.

21 See: P. Roszak, J. Vijgen, Towards a 'Biblical Thomism': Introduction, pp. VII-XVI.

22 „Ad hoc ergo quod sit perfecta, oportet quod ascendat et consequatur ipsum finem rei contemplatae, inhaerendo et assentiendo per affectum et intellectum veritati contemplatae". Super Io., pr. 1 
derstanding (intellectum) ${ }^{23}$. This is because human knowledge, which revolves around the existing reality is done through intellect and not a process, but an act of having an end. It describes the mechanism which is a human intellectual activity by using the category of generation (generatio) and conception (conceptio). They consistently show that the principle of this kind of activity is the existing of reality and that through species intelligibilis it causes a change in the intellect. Giving birth is a testament of the real effect and manifestation of intellect. The words of the heart (verbum cordis), are different from species intelligibilis on the principle that takes place between the beginning and the end of (terminus principium ${ }^{24}$. This points not only to knowledge (mainly metaphysics), which arises from the contact with reality, but also to the entire set of actions that are taken under its influence. All reactions of the will in the form of affection and inclination ${ }^{25}$ are bound with early intellectual knowledge, and carried out by the direct result of the word of the heart. This point perfectly describes a specific type of intellectualism of Aquinas - intellect though ahead of any action of the will, has an end, which is understanding, not without volitional reaction (it is not purely speculative). The best example can be love, for as an act of will is carried out under an earlier understanding of the word, stimulating us to love ${ }^{26}$.

How do these sublime (but ultimately implemented within the metaphysics of discovery) remarks refer to the biblical understanding? When Aquinas in his Quodlibetales draws attention to the difference between the cognitive and intellectual form of the words of the heart, he indicates that the latter can apply to both the concept of something unfolded (intelligentia indivisibilium), as well as

23 We can find theory of the word (in epistemological sense) and especially word of the heart in De veritate (q. 4, a. 1), and Quaestiones Quodlibetales (V, q. 5, a. 2, co), Contra Gentiles (IV, c. 11). See: L. Szyndler, Zagadnienie «verbum cordis» w ujęciu Tomasza z Akwinu, pp. $21-115$.

24 Cfr. H. Goris, Theology and Theory of the Word, pp. 62-72; 75.

25 "Intellectus enim fit in actu per formam intelligibilem inquantum est intelligens, sicut res naturalis fit actu in esse naturali per propriam formam. Res autem naturalis per formam qua perficitur in sua specie, habet inclinationem in proprias operationes et proprium finem, quem per operationes consequitur: quale enim est unumquodque, talia operatur, et in sibi convenientia tendit. Unde etiam oportet quod ex forma intelligibili consequatur in intelligente inclinatio ad proprias operationes et proprium finem. Haec autem inclinatio in intellectuali natura voluntas est, quae est principium operationum quae in nobis sunt, quibus intelligens propter finem operatur: finis enim et bonum est voluntatis obiectum". Contra Gentiles IV, c. 19.

26 "Manifestum est autem quod nihil amare possumus intelligibili et sancto amore nisi quod actu per intellectum concipimus. Conceptio autem intellectus est verbum: unde necesse est quod amor a verbo oriatur". De rationibus fidei, c. 4. 
the expression which testifies to the action of intellect connecting and sharing (intellectus componentis et dividentis) ${ }^{27}$.

In a surprising way he adds that even if species intelligibilis is always the beginning of word procreation, it is also a word (external, spoken by others, not being itself) and may also be the reason for the procreation in the human intellect of the words of the heart, "in a sense, the word itself can be called a form of intelligible species, provided that it is established by the intellect, as an art form that finds the intellect"28. This is referred to as a specific form of intellectual learning.

\section{Conclusion}

Only in this context can we understand Thomas's remarks about the relationship between the literal and spiritual sense, and the uniqueness of the field which is the sacra doctrina according to his point of view. In a literal (historical) sense the Scriptures are related to the situation in which the words mean things. The spiritual sense is determined essentially by the literal sense, which occurs when things identified by the words mean signify something superfluous, and represent more things in perspective, of what a man should do for eternal life ${ }^{29}$. Aquinas removed the question of ambiguity of the multiplicity of senses, because one word does not mean many things, but "the things signified by the words themselves can be other types of things" 30 . And although in any

27 "Est autem duplex operatio intellectus, secundum philosophum in III De anima. Una quidem quae vocatur indivisibilium intelligentia, per quam intellectus format in seipso definitionem, vel conceptum alicuius incomplexi. Alia autem operatio est intellectus componentis et dividentis, secundum quam format enuntiationem. Et utrumque istorum per operationem intellectus constitutorum vocatur verbum cordis, quorum primum significatur per terminum incomplexum, secundum vero significatur per orationem. Manifestum est autem quod omnis operatio intellectus procedit ab eo secundum quod est factus in actu per speciem intelligibilem, quia nihil operatur nisi secundum quod est actu. Unde necesse est quod species intelligibilis, quae est principium operationis intellectualis, differat a verbo cordis, quod est per operationem intellectus formatum". Quodlibet V, q. 5, a. 2, co. See also: Super Sent., lib. 3, d. 24, q. 1, a. 1, qc. 2, ad 2; De veritate, q. 1, a. 3, co; Contra Gentiles II, c. 76.

28 "[...] quamvis ipsum verbum possit dici forma vel species intelligibilis, sicut per intellectum constituta, prout forma artis quam intellectus adinvenit, dicitur quaedam species intelligibilis". Quodlibet V, q. 5, a. 2, co.

29 See. T. Bellamah, Qui primo per verba intenditur - Notes on Thomas's Understanding of Authorial Intention and Literal Sense, pp. 268-271.

30 „Illa vero significatio qua res significatae per voces, iterum res alias significant, dicitur sensus spiritualis". S.Th. I, q. 1, a. 10, co. 
kind of knowledge, the word has the ability to signify an object, but in commented the Scripture it is something special, because it is associated with the items marked by words that can denote something else. In this way, the rules of faith written in Aquinas's comments, can become a sufficient basis for building not only biblical theology and the sacra doctrina, but also the lecture on speculative theology.

\section{Bibliography}

Andrzejuk I., Człowiek i kontemplacja. Antropologiczne podstawy poznania Boga w rozumieniu Aleksandra Żychlińskiego, Rocznik Tomistyczny 2 (2013), pp. 169-181.

Bellamah T., Qui primo per verba intenditur - Notes on Thomas's Understanding of Authorial Intention and Literal Sense, in: M. Paluch, P. Lichacz (eds.), Dominicans adn the Chellenge of Thomism, Warszawa 2012, pp. 261-277.

Bellamah T., The Interpretation of A Contemplative: Thomas' Commentary «Super Iohannem», in: P. Roszak, J. Vijgen (eds.), Reading Sacred Scripture with Thomas Aquinas. Hermeneutical Tools, Theological Quaestions and New Perspectives, Brepols, Turnhout 2015, pp. 229-255.

Gogacz M., Modlitwa i mistyka, Wydawnictwo „Michalineum”, Kraków-Warszawa/ /Struga 1987.

Goris H., Theology and Theory of the Word, in: M. Dauphinais, B. David, M. Levering, Aquinas the Augustinian, CUA, Washington 2007, pp. 62-78.

Idźkowski J., Próba wyjaśnienia, czym jest kontemplacja wedtug św. Tomasza z Akwinu, in: M. Manikowski (ed.), Człowiek i świat wokót niego. Studia z filozofii średniowiecznej, Wrocław 2008, pp. 65-71.

Milewski D., Rycerz A., Dar rozumu, in: M. Mróz (ed.), Dary Ducha Świętego. Materiały z ćwiczeń, Wyższe Seminarium Duchowne, Toruń 2001, pp. 85-95.

Pinsent A., The Gifts and Fruits of the Holy Spirit, in: B. Davies, E. Stump (eds.), The Oxford Handbook of Aquinas, Oxford University Press 2012, pp. 475-488.

Romaniuk K., O siedmiu Darach Ducha Świętego, Wydawnictwo “M”, Kraków 2013.

Roszak P., Vijgen J., Towards a 'Biblical Thomism': Introduction, in: P. Roszak, J. Vijgen (eds.), Reading Sacred Scripture with Thomas Aquinas. Hermeneutical Tools, Theological Quaestions and New Perspectives, Brepols, Turnhout 2015, pp. VII$-X V I$.

Roszak P., Wiarygodność i tożsamość. "Teologia wiary» św. Tomasza z Akwinu i współczesność, WAM, Kraków 2013.

Szyndler L., Zagadnienie «verbum cordis» w ujęciu Tomasza z Akwinu, in: Wokót średniowiecznej filozofi języka, Warszawa 2002, pp. 21-115.

Torrell J.-P., Święty Tomasz z Akwinu. Mistrz duchowy, transl. by A. Kuryś, "W drodze," Poznań-Warszawa 2003. 